\title{
PENGEMBANGAN INDUSTRI PENGOLAHAN PERIKANAN DALAM PENGEMBANGAN EKONOMI LOKAL
}

\section{THE DEVELOPMENT OF FISHERIES INDUSTRY IN THE LOCAL ECONOMIC DEVELOPMENT}

\author{
Sigit Riyanto $^{1}{ }^{*}$, Fadjar Hari Mardiansjah ${ }^{2)}$ \\ 1) UPTD Metrologi Legal Kota Semarang \\ ${ }^{2)}$ Magister Pembangunan Wilayah dan Kota UNDIP Semarang \\ *Email : sgt_rynt@yahoo.com
}

\begin{abstract}
Pati Regency is one of the regions in Central Java Province that has a large potential of fisheries and marine. However, only about $52.11 \%$ of fishery production is processed. The research objective is to study the development of the fisheries processing industry in the development of the local economy in Pati Regency. The study used a mix-method method in August-October 2018. The research locations were Juwana, Tayu, Batangan, Dukuhseti, Margoyoso, Wedarijaksa, Trangkil, Pati, Sukolilo, Kayen, Winong, Gabus, Jaken, Jakenan, Tambakromo, Gembong and Margorejo subdistrict. Data collection techniques through observation, questionnaires, in-depth interviews and document review. Sampling is simple random sampling with the number of sample are 90 fisheries processing industry players. Quantitative analysis was carried out to find out the characteristics of a fishery processing industry that is numerical, namely the distribution statistics tabulation data. (2) Analysis of factors affecting the fisheries processing industry using confirmatory factor analysis (CFA) using a questionnaire. The results of the study: significant factors affecting the fisheries processing industry, namely raw materials, institutions, industrial infrastructure and industrial locations. Alternative strategies include improving industrial infrastructure, enhancing community and institutional capacity. Development of a fishery processing industry integrated with raw materials.
\end{abstract}

Keywords : fisheries processing, local economy, strategy

\begin{abstract}
ABSTRAK
Kabupaten Pati merupakan salah satu daerah di Provinsi Jawa Tengah yang memiliki potensi perikanan dan kelautan yang cukup besar. Namun hanya sekitar 52,11\% dari produksi perikanan yang dilakukan pengolahan. Tujuan penelitian untuk melakukan kajian pengembangan industri pengolahan perikanan dalam pengembangan ekonomi lokal di Kabupaten Pati. Penelitian dilaksanakan pada bulan AgustusOktober 2018 dengan menggunakan pendekatan kualitatif-kuantitatif (mix-method). Lokasi penelitian yaitu Kecamatan Juwana, Tayu, Batangan, Dukuhseti, Margoyoso, Wedarijaksa, Trangkil, Pati, Sukolilo, Kayen, Winong, Gabus, Jaken, Jakenan, Tambakromo, Gembong dan Margorejo. Teknik pengumpulan data melalui observasi, kuesioner, wawancara mendalam dan telaah dokumen. Teknik pengambilan sampel adalah simple random sampling dengan jumlah sampel 90 pelaku industri pengolahan perikanan. Analisis kuantitatif dilakukan untuk mengetahui karakteristik industri pengolahan perikanan yang bersifat numerik yaitu datadata tabulasi statistik distribusi. Analisis faktor yang mempengaruhi industri pengolahan perikanan menggunakan analisis faktor konfirmatori (CFA). Hasil penelitian menunjukkan bahwa faktor yang berpengaruh terhadap industri pengolahan perikanan adalah bahan baku, kelembagaan, infrastruktur industri dan lokasi industri. Alternatif strategi antara lain 1) peningkatan infrastruktur industri; 2) peningkatan kapasitas masyarakat dan kelembagaan; serta 3) pengembangan industri pengolahan perikanan yang terintegrasi dengan bahan baku.
\end{abstract}

Kata kunci : pengolahan perikanan, ekonomi lokal, strategi 


\section{PENDAHULUAN}

Ketimpangan pembangunan antar daerah di Indonesia merupakan aspek yang umum terjadi dalam kegiatan ekonomi suatu daerah terutama pada era desentralisasi. Perubahan paradigma baru dalam hal pembangunan telah terjadi pada sistem desentralisasi (Tang \& Huhe, 2016). Sistem desentralisasi memberikan kewenangan kepada daerah untuk mengatur pemerintahan dan fungsi-fungsi tertentu (Kuncoro, 2004). Diperlukan upaya memanfaatkan potensi daerah yang ada guna melaksanakan pembangunan sehingga mampu mengurangi ketimpangan wilayah dalam rangka meningkatkan kesejahteraan masyarakat.

Salah satu sektor yang menjadi kewenangan pemerintah daerah adalah pengelolaan sumber daya perikanan (Satria \& Matsida, 2004). Provinsi Jawa Tengah merupakan salah satu provinsi yang memiliki kekayaan sumber daya perikanan dan kelautan yang dapat dijadikan modal pembangunan daerah.

Tujuan pembangunan industri Provinsi Jawa Tengah 2015-2035 yaitu terwujudnya industri Jawa Tengah yang berdaya saing dan berkesinambungan. Pemerintah Provinsi Jawa Tengah menetapkan pengembangan perwilayahan industri sesuai dengan potensi sumber daya yang ada agar terjadi pemerataan industri di wilayah Provinsi Jawa Tengah. Salah satunya adalah menetapkan wilayah yang dapat dikembangkan industri pengolahan perikanan di daerah yang memiliki potensi perikanan \& kelautan. Wilayah yang dimaksud meliputi 2 kota dan 7 kabupaten yaitu Kota Tegal, Kota Pekalongan, Kabupaten Batang, Brebes, Cilacap, Demak, Kendal, Pati, dan Rembang.

Kabupaten Pati secara geografis berbatasan dengan Laut Jawa di sebelah utara dan timur. Berdasarkan letak geografisnya, Kabupaten Pati memiliki potensi perikanan yang besar baik perikanan tangkap maupun perikanan budidaya. Kabupaten Pati pada tahun 2015 merupakan kabupaten yang memiliki produksi perikanan terbesar di Provinsi Jawa Tengah (BPS Jawa Tengah, 2015).

Manfaat keberadaan industri pengolahan perikanan antara lain untuk memanfaatkan produk perikanan, mengawetkan dan menjaga kualitas produk perikanan yang mudah rusak serta memberikan nilai tambah produk perikanan (Yang et al., 2016; Bar, 2015). Pengembangan industri pengolahan perikanan diharapkan mampu meningkatkan kesempatan kerja serta mengurangi kemiskinan.

Berdasarkan data dari Dinas Kelautan dan Perikanan Kabupaten Pati Tahun 2015, sekitar $52,11 \%$ dari potensi perikanan dan kelautan telah dilakukan pengolahan. Peningkatan produksi perikanan dan kelautan di Kabupaten Pati tidak sebanding dengan pertumbuhan industri pengolahan perikanan yang relatif stagnan. Berdasarkan permasalahan tersebut, penelitian ini bertujuan untuk melakukan kajian pengembangan industri pengolahan perikanan dalam pengembangan ekonomi lokal di Kabupaten Pati.

\section{TINJAUAN PUSTAKA}

Pembangunan lokal dan regional merupakan pembangunan yang berfokus pada pembangunan ekonomi, meliputi pertumbuhan penyediaan lapangan kerja, dan peningkatan kesejahteraan sebagai upaya untuk mengurangi ketimpangan sosial, keberlanjutan lingkungan, mendorong peran pemerintah dalam mengelola keragaman (Pike et al., 2013). Paradigma pembangunan telah berubah dari konsep pembangunan klasik berbasis keunggulan komparatif dan membangun sektor ekonomi secara homogenisasi menjadi pengembangan ekonomi lokal berbasis pada keunggulan kompetitif dan menjaga kelestarian lingkungan dan menggunakan prinsip 
pengetahuan sebagai penggerak ekonomi dan kemitraan (Tomlinson, 2008).

Pengembangan ekonomi lokal adalah suatu proses dimana pemerintah daerah dan atau kelompok masyarakat mengelola sumber daya yang ada dan mengambil bagian dalam susunan persekutuan (partnership) dengan sektor swasta atau yang lainnya, menciptakan lapangan kerja dan merangsang kegiatan ekonomi dalam zona perekonomian yang telah ditetapkan dengan baik (Blakely, 1984). Pengembangan ekonomi lokal sebagai peningkatan peran elemen-elemen endogenous dalam kehidupan sosial ekonomi suatu lokalitas dengan tetap melihat keterkaitan serta integrasinya secara fungsional dan spasial dengan wilayah yang lebih luas (Coffey et al., 1984).

Industri pengolahan perikanan adalah usaha pengolahan hasil perikanan/organisme yang hidup di air untuk tujuan komersial/ industri baik hasil budidaya maupun hasil tangkap (Thrane et al., 2009). Usaha pengolahan ikan merupakan istilah umum yang mendefinisikan penanganan pasca produksi tangkap atau panen budidaya menggunakan sarana prasarana dan teknologi. Pengolahan perikanan dilakukan untuk meningkatkan nilai tambah terhadap produk perikanan dan berfungsi untuk mengawetkan ikan karena bersifat mudah rusak dan busuk (Bar, 2015). Industri pengolahan perikanan dilakukan sesuai dengan jenis komoditas ikan serta selera konsumen. Secara teknik industri pengolahan perikanan terbagi menjadi industri pengolahan tradisional dan modern. Industri pengolahan perikanan tradisonal seperti pemanggangan, pemindangan, pengeringan, pengasinan dan pengolahan lain menggunakan peralatan dan teknik sederhana. Sementara industri pengolahan perikanan modern seperti pembekuan, pengalengan dan diversifikasi olahan lain yang telah menggunakan inovasi teknologi.
Menurut Freeman et al (2012) pemangku kepentingan merupakan kelompok atau individu yang dapat mempengaruhi atau yang terpengaruh selama proses pencapaian tujuan suatu organisasi. Analisis pemangku kepentingan merupakan suatu proses mengidentifikasi individu, kelompok, \& organisasi yang dipengaruhi atau dapat mempenga-ruhi lingkungan dan generasi yang akan datang serta memprioritaskan individu-individu yang terlibat dalam proses pengambilan keputusan (Reed et al., 2009). Terdapat tiga tahapan dalam analisis pemangku kepentingan, yaitu mengidentifikasi pemangku kepentingan, mengklasifikasikan pemangku kepentingan dan menyelidiki hubungan antar pemangku kepentingan (Reed et al., 2009).

Kemitraan antar pemangku kepentingan dalam industri pengolahan perikanan mutlak diperlukan sesuai dengan amanat UndangUndang Nomor 20 tahun 2008 tentang Usaha Mikro, Kecil, dan Menengah (UMKM). Mengingat skala industri pengolahan perikanan di Kabupaten Pati berskala IKM, pola kemitraan yang dapat dilakukan dalam industri pengolahan perikanan sesuai dengan undang-undang tersebut adalah pola inti-plasma, subkontrak, waralaba, keagenan, bagi hasil, perdagangan umum, dan kemitraan lainnya.

\section{METODE PENELITIAN}

Penelitian ini dilaksanakan selama 3 (tiga) bulan, mulai bulan Agustus sampai dengan Oktober 2017 Penelitian dilaksanakan di 17 (tujuh belas) kecamatan di Kabupaten Pati yang memiliki potensi industri pengolahan perikanan yaitu Kecamatan Juwana, Tayu, Batangan, Dukuhseti, Margoyoso, Wedarijaksa, Trangkil, Pati, Sukolilo, Kayen, Winong, Gabus, Jaken, Jakenan, Tambakromo, Gembong dan Margorejo.

Pengumpulan data dilakukan melalui observasi, kuesioner, wawancara mendalam 
dan telaah dokumen. Metode pengambilan sampel responden kuesioner adalah simple random sampling. Berdasarkan perhitungan Slovin, jumlah sampel adalah 90 pelaku industri pengolahan perikanan. Pengambilan sampel wawancara mendalam dilakukan menggunakan teknik purposive sampling terhadap pemangku kepentingan industri pengolahan perikanan di Kabupaten Pati.

Penelitian menggunakan pendekatan kualitatif-kuantitatif (mix-method). Metode penelitian mix-method menurut Creswel (2014) adalah pendekatan penelitian yang menggabungkan atau menghubungkan metode penelitian kuantitatif dan kualitatif. Analisis kuantitatif dilakukan untuk mengetahui karakteristik industri pengolahan perikanan yang bersifat numerik yaitu data-data tabulasi statistik distribusi. Analisis faktor yang mempengaruhi industri pengolahan perikanan menggunakan analisis faktor konfirmatori (CFA) menggunakan kuesioner. Hasil analisis faktor digunakan sebagai bahan wawancara untuk merumuskan strategi pengembangan. Data diolah mengunakan software IBM SPSS Statistik 23 untuk menguji validitas, reliabilitas dan faktor loading.

Identifikasi kerja sama atau kemitraan dilakukan melalui tiga tahapan yaitu identifikasi pemangku kepentingan, klasifikasi pemangku kepentingan dan identifikasi hubungan antar pemangku kepentingan. Arahan pengembangan industri pengolahan perikanan di Kabupaten Pati dilakukan melalui wawancara (indepth-interview) sesuai dengan hasil analisis faktor dan karakterisktik industri pengolahan perikanan.

\section{HASIL DAN PEMBAHASAN}

\section{Identifikasi Karakteristik Industri Pengo- lahan Perikanan di Kabupaten Pati}

Berdasarkan hasil kuesioner terhadap pelaku usaha perikanan dan kelautan, bahan baku industri pengolahan perikanan di Kabupaten Pati mencukupi dan kontinyu serta memiliki kualitas yang baik. Hal ini dikarenakan sarana pra-sarana pendukung telah dilengkapi oleh seperti cold storage, kapal serta alat transportasi yang memiliki pendingin/freezer. Sumber daya manusia pengolah perikanan berasal dari tenaga kerja lokal dan umumnya memiliki kualitas pendidikan yang relatif rendah. Keterampilan dan pelatihan kerja dilakukan melalui praktek dan pengamatan secara langsung.

Lokasi industri pengolahan perikanan umumnya berdekatan dengan bahan baku karena sifat ikan yang mudah rusak dan busuk. Oleh karena itu, industri pengolahan perikanan berada di sepanjang wilayah yang berbatasan dengan Laut Jawa. Pendirian industri pengolahan perikanan juga mempertimbangkan kedekatan dengan lokasi pemasaran mengingat kualitas produk olahan yang relatif rendah dan tidak bertahan lama. Permodalan industri pengolahan perikanan telah didukung oleh Lembaga Keuangan/Bank melalui program Kredit Usaha Rakyat (KUR). Dimana proses pengajuannya dipermudah oleh Bank dengan melengkapi beberapa persyaratan misalnya ijin usaha mikro kecil (IUMK).

Industri pengolahan perikanan di Kabupaten Pati telah didukung sarana prasarana infrastruktur yang baik. Kondisi jalan serta kapasitas jalan telah mendukung transportasi. Alat transportasi memiliki kualitas yang baik karena telah dilengkapi dengan pendingin/freezer sehingga mampu mempertahankan kualitas bahan baku maupun produk hasil pengolahan perikanan dan kelautan.

Industri pengolahan perikanan di Kabupaten Pati telah didukung oleh infrastruktur industri seperti lahan industri, prasarana listrik, telekomunikasi, air, dan sebagainya. Namun peralatan yang digunakan 
umumnya masih sederhana karena teknik pengolahannya bersifat sederhana. Terdapat 8 (delapan) unit Pelabuhan Pendaratan Ikan (PPI) atau Tempat Pelelangan Ikan (TPI) yang berfungsi untuk mendukung penyediaan bahan baku perikanan laut. Tersedia 8 unit cold storage milik swasta untuk mendukung ketersediaan dan kontinuitas bahan baku. Pengelolaan sampah juga sudah relatif baik. Sampah padat berupa bagian ikan yang tidak digunakan dikumpulkan sebagai pakan ternak. Air limbah pengolahan perikanan belum dikelola dengan baik hanya dibuang secara langsung ke sungai. Beberapa pengolahan masih dilakukan di lantai dan menggunakan air dari sungai untuk mencairkan ikan.

Pemerintah senantiasa melakukan pelatihan, pembinaan dan pendampingan untuk mendukung pengembangan industri pengolahan perikanan. Klaster/kelompok pengolah telah tumbuh pada masing-masing sentra industri pengolahan perikanan. Beberapa kelompok bahkan telah membentuk lembaga koperasi yang bergerak di sektor riil maupun simpan pinjam. Lembaga kelompok pengolah tersebut digunakan sebagai wadah kemitraan antara pemerintah, swasta dan masyarakat.

Kemitraan antara pemerintah dengan masyarakat telah terjalin dengan kuat. Hal ini ditunjukkan adanya pendampingan, penyuluhan dan program kegiatan yang dilakukan secara rutin oleh pemerintah. Kemitraan antar masyarakat dan swasta terutama industri besar pengolahan perikanan masih relatif lemah dan terbatas pada pengadaan bahan baku melalui cold storage dan bahan pendukung melalui koperasi dengan sistim perdagangan umum.

Pemasaran produk perikanan telah menjangkau berbagai daerah di Pulau Jawa, Sumatera, Kalimantan dan Bali. Bahkan beberapa produk pengolahan misalnya kerupuk ikan, nugget, bakso ikan dan sebagainya telah menjangkau pasar ekspor seperti di Taiwan, Jepang dan beberapa negara di Asia Tenggara. Permintaan produk perikanan senantiasa bertambah sebanding dengan kenaikan angka konsumsi ikan. Namun strategi pemasaran produk pengolahan perikanan masih tergantung kepada pedagang/ tengkulak melalui pemesanan/job order dan belum memanfaatkan media elektronik dalam mempromosikan produk pengolahan perikanan.

Industri pengolahan perikanan di Kabupaten Pati telah didukung kemudahan dalam hal perijinan usaha secara terpadu satu pintu. Sementara izin usaha mikro kecil (IUMK) dapat dilakukan di tingkat kecamatan. Terdapat keterkaitan ekonomi yang tinggi antar pelaku usaha dan pelaku utama dalam industri pengolahan perikanan mulai dari nelayan, pembudidaya maupun pedagang pengumpul, tenaga kerja pengolahan dan pemasar produk pengolahan perikanan.

Pemerintah Kabupaten Pati telah menetapkan pola ruang melalui Peraturan Daerah Kabupaten Pati Nomor 5 Tahun 2011 tentang Rencana Tata Ruang Wilayah Kabupaten Pati Tahun 2010-2030. Berdasarkan Perda tersebut, kawasan peruntukan industri besar perikanan dapat dikembangkan di Kecamatan Juwana dan Batangan. Industri pengolahan perikanan berskala kecil dan menengah dapat dikembangkan di seluruh kecamatan. Hal ini memberikan perlindungan hukum serta mempermudah perizinan apabila masyarakat akan mendirikan industri pengolahan perikanan.

Identifikasi Kerja Sama/Kemitraan Pemangku Kepentingan Industri pengolahan Perikanan di Kabupaten Pati

\section{a. Identifikasi Pemangku Kepentingan Industri Pengolahan Perikanan}

Pemangku kepentingan industri pengolahan perikanan dapat dikelompokkan menjadi 
tiga, yaitu pemangku kepentingan kunci, pemangku kepentingan dalam industri pengoutama dan pendukung (Crosby, 1991). lahan perikanan dapat berbentuk regulator, Pengelompokan tersebut berdasarkan peran implementator, fasilitator, advocator maupun pemangku kepentingan dalam industri pengo- evaluator (Nurfatriani et al., 2015). Persebaran lahan perikanan di Kabupaten Pati. Peran dari pemangku kepentingan disajikan pada Tabel 1.

Tabel 1.

Pemangku Kepentingan Industri Pengolahan Perikanan di Kabupaten Pati

\begin{tabular}{|c|c|c|}
\hline Stakeholder Kunci & Stakeholder Utama & $\begin{array}{l}\text { Stakeholder } \\
\text { Penunjang }\end{array}$ \\
\hline $\begin{array}{l}\text { Merupakan inisiator secara } \\
\text { legalitas memiliki } \\
\text { kewenangan pengambilan } \\
\text { kebijakan yang terdiri dari } \\
\text { instansi pemerintah yang } \\
\text { terkait langsung dengan } \\
\text { industri pengolahan } \\
\text { perikanan } \\
\text { 1. Dinas Kelautan dan } \\
\text { Perikanan } \\
\text { 2. Dinas Perindustrian dan } \\
\text { Perdagangan } \\
\text { 3. Dinas Koperasi dan } \\
\text { UMKM } \\
\text { 4. Bappeda } \\
\text { 5. Dinas PUPR } \\
\text { 6. Dinas Penanaman Modal } \\
\text { 7TSP } \\
\text { 7. Dinas Lingkungan Hidup } \\
\text { 8. Dinas Kesehatan } \\
\text { 9. FEDEP } \\
\text { 10. Kecamatan,Desa } \\
\text { 11. BDS-P } \\
\text { 12. Penyuluh Perikanan }\end{array}$ & $\begin{array}{l}\text { Merupakan sektor swasta, } \\
\text { pelaku usaha yang } \\
\text { mengimplementasikan } \\
\text { kebijakan dalam aktifitas } \\
\text { bisnis dan terkena dampak } \\
\text { dari kebijakan } \\
\text { 1. Kelompok Pengolah dan } \\
\text { Pemasar (POKLAHSAR) } \\
\text { Ikan } \\
\text { 2. Pengolah perikanan } \\
\text { 3. Nelayan } \\
\text { 4. Pembudidaya ikan } \\
\text { 5. Pemasar/pedagang kecil } \\
\text { 6. Tengkulak/pedagang besar } \\
\text { 7. Industri besar pengolahan } \\
\text { perikanan }\end{array}$ & $\begin{array}{l}\text { Merupakan pihak yang } \\
\text { tidak memiliki kaitan } \\
\text { secara langsung namun } \\
\text { memiliki kepedulian } \\
\text { terhadap kebijakan } \\
\text { termasuk pemerhati dan } \\
\text { pemberi masukan dan } \\
\text { kritik } \\
\text { 1. Akademisi } \\
\text { (Universitas atau } \\
\text { peneliti yang meneliti } \\
\text { tentang industri } \\
\text { pengolahan } \\
\text { perikanan) } \\
\text { 2. Lembaga keuangan } \\
\text { (Bank dan Koperasi) } \\
\text { 3. LSM }\end{array}$ \\
\hline
\end{tabular}

\section{b. Klasifikasi Pemangku Kepentingan Industri Pengolahan Perikanan}

Menurut Eden dan Ackerman dalam Reed et al., (2009) pengelompokan stakeholder terbagi ke dalam 4 (empat) kelompok berdasarkan hasil matriks pengaruh dan kepentingan. Pengaruh berhubungan dengan kekuatan yang dimiliki oleh stakeholder untuk mengontrol proses dan hasil dari suatu keputusan menggunakan variabel kekuatan (power), yaitu kekuatan kompensasi, kekuatan individu, kekuatan kondisi, kekuatan kelayakan dan kekuatan organisasi (Galbraith dalam Reed et al., 2009). Sementara kepentingan berhubungan dengan kebutuhan stakeholder di dalam pencapaian output dan tujuan (Reed et al., 2009) yang terdiri dari variabel keterlibatan stakeholder, produksi, habitat, 
carrier dan fungsi informasi (de Groot et al, 2006 dalam Reed et al., 2009). Adapun pengelompokan stakeholder industri pengolahan perikanan di Kabupaten Pati ditunjukkan pada Gambar 1.

Kuadran I yaitu kelompok Subjects yaitu kelompok pemangku kepentingan yang memiliki kepentingan tinggi namun pengaruh yang rendah. Kelompok tersebut adalah kelompok pelaku usaha dan pelaku utama perikanan dan kelautan yang terdiri dari masyarakat pengolah perikanan, pedagang/ tengkulak, nelayan dan pembudidaya, industri besar (swasta) pengolahan perikanan, dan kelompok pengolah dan pemasar (POKLAHSAR) hasil perikanan. Kelompok ini bertindak sebagai pelaku industri pengolahan perikanan dan bersifat supportive karena memiliki kapasitas yang kecil untuk mempengaruhi atau mengubah situasi.

Kuadran II yaitu kelompok Key Players yang memiliki pengaruh dan kepentingan yang tinggi. Kelompok ini terdiri dari Dislautkan, Disdagperin, Dinkop UMKM, FEDEP, Penyuluh perikanan, Bappeda, dan BDS-P (Businnes Development Services Provider). Kelompok ini merupakan kelompok kritis atau pelaku utama dalam industri pengolahan perikanan karena secara legalitas kelompok ini memiliki pengaruh kekuatan dan kewenangan yang tinggi serta memiliki tangung jawab terhadap industri pengolahan perikanan sehingga memiliki kebutuhan yang tinggi terhadap pencapaian tujuan organisasi.

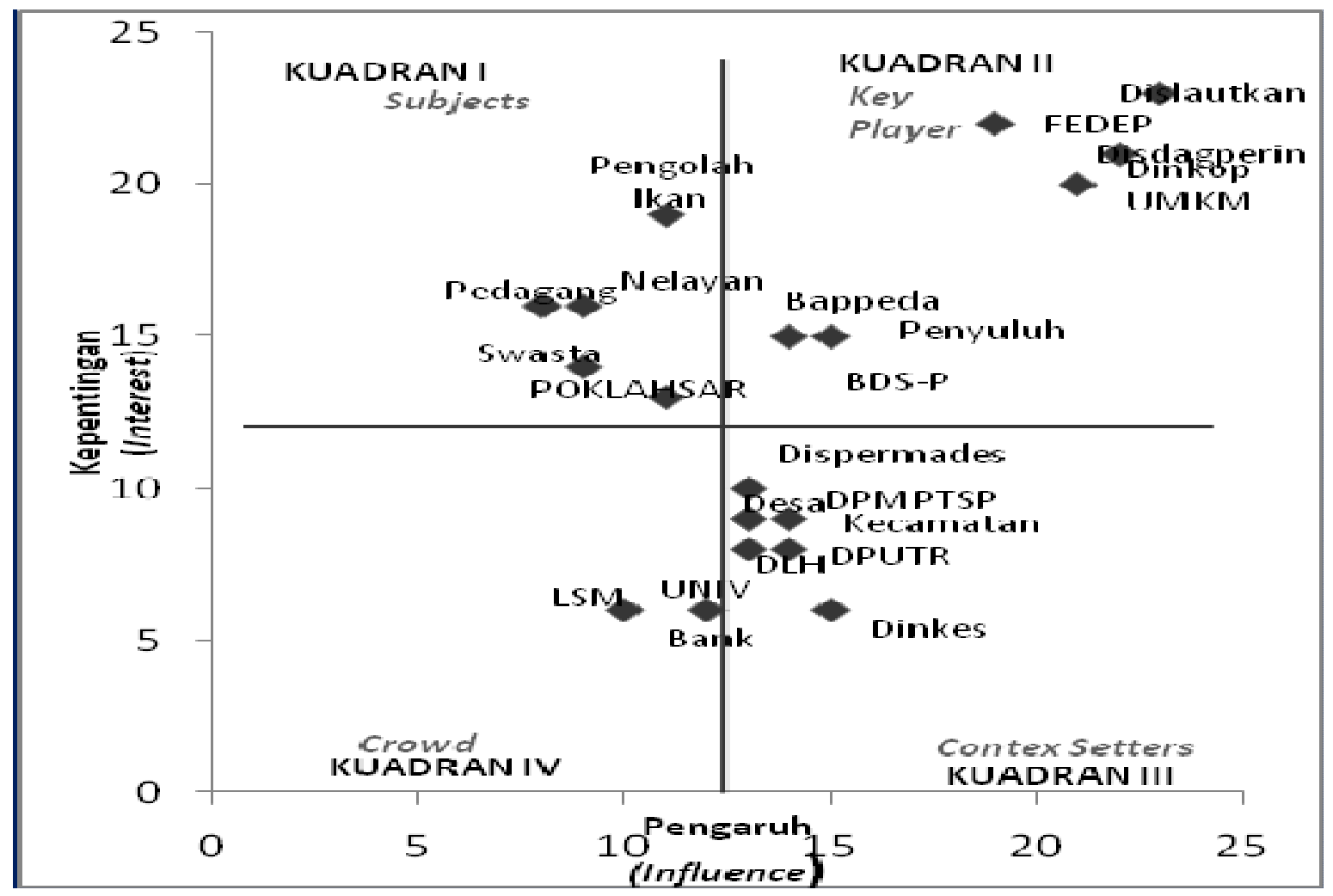

Gambar 1.

Matriks Pengaruh dan Kepentingan Pemangku Kepentingan Industri Pengolahan Perikanan di Kabupaten Pati 
Kuadran III adalah Contex Setters yang memiliki pengaruh tinggi namun memiliki kepentingan rendah. Kelompok ini terdiri dari Dispermades, DPUTR, DLH, DPMPTSP, Dinkes, Kecamatan dan Desa. Pemangku kepentingan ini memiliki peran dalam industri pengolahan perikanan sesuai dengan tugas pokok fungsinya masing-masing, namun memiliki tanggung jawab yang relatif rendah atau memiliki keterkaitan secara tidak langsung. Pemangku kepentingan ini merupakan kelompok yang harus dipantau karena dapat menimbulkan resiko yang signifikan.

Kuadran IV adalah Crowd yang memiliki pengaruh dan kepentingan rendah . Namun kelompok ini dapat mengalami perubahan terkait pengaruh dan kepentingannya sehingga kelompok ini perlu menjadi pertimbangan dalam pengambilan keputusan. Meskipun memiliki pengaruh dan kepentingan yang rendah, pemangku kepentingan ini mendukung industri pengolahan perikanan. Kelompok ini terdiri dari Perguruan Tinggi, Lembaga Keuangan/Bank, dan Lembaga Swadaya Masyarakat (LSM).

\section{c. Hubungan Pemangku Kepentingan Industri Pengolahan Perikanan}

Hubungan pemangku kepentingan industri pengolahan perikanan dapat berpotensial saling bekerja sama, saling melengkapi dan konflik (Reed et al., 2009). Hubungan pemangku kepentingan industri pengolahan perikanan diilustrasikan menggunakan matriks actor linkage. Dimana pemangku kepentingan terdapat pada baris dan kolom, sementara hubungan pemangku kepentingan terdapat didalamnya. Adapun hubungan pemangku kepentingan industri pengolahan perikanan di Kabupaten Pati ditunjukkan pada Tabel 2.

\section{d. Kerja sama/Kemitraan Pemangku Kepentingan Industri Pengolahan Perikanan}

Kerja sama/kemitraan yang terjadi antar pelaku usaha pengolahan perikanan terbatas pada kemitraan pengadaan bahan pendukung besek dan tali pada proses pengolahan pemindangan dari Koperasi Rukun Mina Barokah. Kemitraan modal dari Koperasi BMT Binsani dan Kopwan wanita Mina Melati milik kelompok pengolah. Kemitraan pelaku usaha pengolahan perikanan dengan swasta industri besar berbentuk pola perdagangan umum dalam pengadaan bahan baku malalui cold storage dan perusahaan membeli beberapa produk tertentu pengolahan perikanan dari masyarakat.

Tabel 2.

Hubungan Pemangku Kepentingan Industri Pengolahan Perikanan

\begin{tabular}{lcccccc}
\hline & $\begin{array}{c}\text { Instansi } \\
\text { Pemerintah }\end{array}$ & Masyarakat & $\begin{array}{c}\text { Swasta } \\
\text { Bisnis }\end{array}$ & $\begin{array}{c}\text { Perguruan } \\
\text { Tinggi }\end{array}$ & Bank & LSM \\
\hline Instansi Pemerintah & A,B & A,C & A,C & A & A & A,B,C \\
Masyarakat & A,C & A,B,C & A,B,C & A & A & A,B \\
Swasta Bisnis & A,C & A,B,C & A,B,C & A & A & A,C \\
Universitas & A & A & A & A,B & A & A,B \\
Bank & A & A & A & A & A,B & A,B \\
LSM & A,B,C & A,B & A,C & A,B & A,B & A,B \\
\hline
\end{tabular}

Keterangan : A) Kerja sama;

B) Saling melengkapi;

C) Konflik 
Kerja sama/kemitraan antara pelaku usaha pengolahan perikanan dengan pemerintah dalam bentuk pendidikan dan pelatihan, bantuan peralatan, penelitian dan pengembangan teknologi, pelayanan informasi dan konsultasi, fasilitasi promosi dan perantara antar pelaku pengolahan perikanan. Kemitraan pelaku usaha pengolahan perikanan dengan Lembaga Keuangan/Bank dalam bentuk kerja sama pembiayaan permodalan usaha melalui program kredit mitra usaha/Kredit Usaha Rakyat (KUR). Kemitraan pelaku usaha pengolahan perikanan dengan Perguruan Tinggi dalam bentuk penelitian dan pengembangan teknologi, pelatihan teknis dan pembinaan. Sementara kemitraan pelaku usaha pengolahan perikanan dengan LSM adalah pelatihan dan pembinaan dalam rangka peningkatan kualitas dan pemberdayaan masyarakat.

\section{Arahan Pengembangan Industri Pengo- lahan Perikanan di Kabupaten Pati}

Strategi pengembangan industri pengolahan perikanan di Kabupaten Pati dibuat berdasarkan hasil analisis faktor yang secara signifikan mempengaruhi industri pengolahan perikanan dengan memperhatikan karakteristik dan kerja sama/kemitraan industri pengolahan perikanan di Kabupaten Pati. Hasil analisis faktor konfirmatori terhadap faktor yang mempengaruhi industri pengolahan perikanan di Kabupaten Pati disajikan pada Tabel 3.

Beberapa faktor yang diperkirakan mempengaruhi industri pengolahan perikanan di Kabupaten Pati adalah bahan baku, sumber daya manusia, kelembagaan, modal dan keuangan, infrastruktur industri, pemasaran, identitas masyarakat, lokasi industri. Hasil analisis faktor menunjukkan faktor bahan baku, kelembagaan, infrastuktur industri dan lokasi industri secara signifikan mempengaruhi industri pengolahan perikanan di Kabupaten Pati. Berdasarkan hasil analisis faktor tersebut, maka arahan pengembangan industri pengolahan perikanan difokuskan kepada faktor bahan baku, kelembagaan, infrastuktur industri dan lokasi industri. Analisis alternatif pengembangan dilakukan secara deskriptif kualitatif melalui wawancara secara mendalam terhadap beberapa informan dari pemangku kepentingan yang terlibat di dalam industri pengolahan perikanan. Alternatif arahan pengembangan industri pengolahan perikanan dalam pengembangan ekonomi lokal di Kabupaten Pati disajikan pada Tabel 4.

Tabel 3.

Analisis Faktor yang Mempengaruhi Industri Pengolahan Perikanan di Kabupaten Pati

\begin{tabular}{lclc}
\hline \multicolumn{1}{c}{ Faktor } & Reliability & \multicolumn{1}{c}{ Faktor } & Reliability \\
\hline Bahan baku & 0,922 & Infrastruktur industri & 0,902 \\
Sumber daya manusia & 0,616 & Pemasaran & 0,785 \\
Kelembagaan & 0,949 & Identitas masyarakat & 0,741 \\
Modal dan keuangan & 0,664 & Lokasi Industri & 0,933 \\
\hline
\end{tabular}


Tabel 4.

Alternatif Strategi Pengembangan Industri Pengolahan Perikanan di Kabupaten Pati

\begin{tabular}{|c|c|c|c|}
\hline No. & Faktor & Strategi Pengembangan & Aktor Terlibat \\
\hline 1 & Bahan baku & $\begin{array}{l}\text { - Peningkatan sistim rantai dingin melalui } \\
\text { peningkatan sarana prasarana mulai dari } \\
\text { hulu sampai hilirnya. } \\
\text { - Pengembangan pembangunan cold } \\
\text { storage terutama perikanan budidaya } \\
\text { - Peningkatan kerja sama/kemitraan } \\
\text { penyedia bahan baku dengan industri } \\
\text { pengolahan perikanan }\end{array}$ & $\begin{array}{l}\text { Dislautkan, penyuluh } \\
\text { perikanan, Swasta, } \\
\text { Nelayan dan } \\
\text { pembudidaya,pengolah } \\
\text { perikanan, pedagang dan } \\
\text { tengkulak. }\end{array}$ \\
\hline 2 & $\begin{array}{l}\text { Lokasi } \\
\text { industri }\end{array}$ & $\begin{array}{l}\text { - Pengembangan industri pengolahan } \\
\text { perikanan yang terintegrasi dengan bahan } \\
\text { baku di kawasan minapolitan }\end{array}$ & $\begin{array}{l}\text { Dislautkan, Kecamatan, } \\
\text { Desa, DPUTR, Pengolah } \\
\text { perikanan }\end{array}$ \\
\hline 3 & Infrastruktur & $\begin{array}{l}\text { - Peningkatan aksesibilitas, pemeliharaan } \\
\text { infrastruktur dan peningkatan kualitas } \\
\text { angkutan umum } \\
\text { - Bantuan peralatan } \\
\text { - Perluasan jaringan air bersih dan } \\
\text { PAMSIMAS } \\
\text { - Peningkatan sarana prasarana TPI } \\
\text { - Perluasan jaringan listrik dan subsidi } \\
\text { biaya listrik } \\
\text { - Pendirian dan pengembangan cold } \\
\text { storage } \\
\text { - Pembinaan dan pendampingan sanitasi } \\
\text { pengolahan produk perikanan }\end{array}$ & $\begin{array}{l}\text { Dislautkan, DPUTR, } \\
\text { Kecamatan, Desa, } \\
\text { swasta, Disdagperin, } \\
\text { Dinkop UMKM, } \\
\text { FEDEP, BDS-P, } \\
\text { Penyuluh perikanan, } \\
\text { DLH, Dispermades, } \\
\text { Desa, Kecamatan, } \\
\text { swasta, pengolah ikan, } \\
\text { penyuluh perikanan, } \\
\text { BDS-P, Perguruan } \\
\text { tinggi, LSM, PDAM }\end{array}$ \\
\hline 4 & Kelembagaan & $\begin{array}{l}\text { - Penguatan kelembagaan kelompok } \\
\text { pengolah perikanan } \\
\text { - Pembinaan dan pendampingan } \\
\text { kelembagaan } \\
\text { - Peningkatan kemitraan pemerintah, } \\
\text { pelaku usaha dan pelaku utama perikanan } \\
\text { dan kelautan, serta swasta } \\
\text { - Peningkatan kompetensi sumber daya } \\
\text { manusia }\end{array}$ & $\begin{array}{l}\text { Dislautkan, FEDEP, } \\
\text { swasta, pelaku usaha dan } \\
\text { pelaku utama perikanan } \\
\text { dan kelautan, BDS-P, } \\
\text { Disdagperin, Dinkop } \\
\text { UMKM, penyuluh } \\
\text { perikanan, BDS-P, LSM, } \\
\text { Perguruan Tinggi }\end{array}$ \\
\hline
\end{tabular}

\section{KESIMPULAN DAN SARAN}

\section{Kesimpulan}

Industri pengolahan perikanan di Kabupaten Pati umumnya berbentuk industri kecil menangah (IKM) pengolahannya masih sederhana dan dilakukan oleh sumber daya manusia yang relatif rendah. Sanitasi proses pengolahan kurang diperhatikan sehingga produk hasil pengolahan perikanan memiliki kualitas yang relatif rendah. kelompok pengolahan perikanan telah berkembang di sentra industri pengolahan perikanan. Terdapat 22 (dua puluh dua) pemangku kepentingan yang 
terlibat dalam industri pengolahan perikanan di Kabupaten Pati yang terdiri dari pemerintah, swasta dan masyarakat. Hubungan pemangku kepentingan berpotensi saling bekerja sama, saling melengkapi dan konflik. Meskipun demikian, hubungan kemitraannya masih relatif lemah dan terbatas pada pola perdagangan umum.

Arahan pengembangan industri pengolahan perikanan di Kabupaten Pati difokuskan kepada faktor yang signifikan berpengaruh terhadap industri pengolahan perikanan. Faktor tersebut adalah faktor bahan baku, kelembagaan, infrastruktur industri dan lokasi industri. Alternatif strategi tersebut antara lain peningkatan infrastruktur industri sehingga mendukung ketersediaan, menjaga kualitas dan kontinuitas bahan baku. Peningkatan kapasitas masyarakat dan kelembagaan sehingga mendorong adanya kemitraan antara pemerintah, swasta dan masyarakat. Pengembangan industri pengolahan perikanan yang terintegrasi dengan bahan baku di lokasi yang telah ditetapkan di dalam pola ruang Rencana Tata Ruang Wilayah (RTRW) Kabupaten Pati.

\section{Saran}

Berdasarkan hasil penelitian terdapat beberapa rekomendasi yaitu:1) pembuatan Peraturan Zonasi dan Rencana Detail Tata Ruang (RDTR) sebagai acuan lokasi pengembangan industri pengolahan perikanan; 2) pembuatan standarisasi produk; 3) pembuatan regulasi pemanfaatan dana CSR untuk meningkatkan kemitraan; 4) peningkatan kapasitas masyarakat secara berkelanjutan.

\section{DAFTAR PUSTAKA}

BPS Jawa Tengah (2015). Provinsi Jawa Tengah dalam Angka 2016. Semarang: BPS Provinsi Jawa Tengah.

Bar, E. S. (2015). A case study of obstacles and enablers for green innovation within the fish pro-cessing equipment industry. Journal of Cleaner Production, 90, 234243.https://doi.org/10.1016/ j.jclepro. 2014.11.055

Blakely, E. J. (1984). Planning local economic development: Theory and practice. California : SAGE Publication

Coffey, W. J., Polese, M. (1984). The Concept of Local development: a Stages Model of Endogeneous Regional Growth. Regional Science, 55(1), 1-12. https://doi.org/10.1111/j.1435-5597. 1984.tb00823.x

Creswel, J. W. (2014), Research Design: Qualitative, Quantitative and Mixed Methods Approaches. California : SAGE Publication Inc.

Crosby, B. L. (1991) Stakeholder Analysis: A vital tool for Strategic Managers. Washington, DC: USAID.

Freeman, R. E., Rusconi, G., Signori, S., Strudler, A. (2012). Stakeholder Theory (ies): Ethical Ideas and Managerial Action. Journal of Business Ethics, 109(1): 1-2. https://doi.org/10.1007/s105 51-012-1374-7

Kuncoro, M. (2004). Otonomi dan Pembangunan Daerah. Jakarta: Erlangga

Nurfatriani, F., Darusman, D., Nurrochmat, D. R., Yustika, A. E. (2015). Analisis Pemangku Kepentingan dalam Transformasi Kebijakan Fiskal Hijau. Jurnal Analisis Kebijakan Kehutanan, 12(2), 105-124.https://doi.org/10.

20886/jakk2015.12.2.105-124

Peraturan Daerah Kabupaten Pati Nomor 5 Tahun 2011 tentang Rencana Tata Ruang Wilayah Kabupaten Pati Tahun 2010-2030 
Pike, A., Rodríguez-Pose, A., Tomaney, J. (2013). Local and regional development in the Global North and South. Progress in Development Studies, 14(1), 21-30. https://doi.org/10.1177/146499341350 4346

Reed, M. S., Graves, A., Dandy, N., Posthumus, H., Hubacek, K., Morris, J., Stringer, L. C. (2009). Who' $\mathrm{s}$ in and why? A typology of stakeholder analysis methods for natural resource management. Journal of Environmental Management, 90(5), 1933-1949. https:// doi.rg/10.1016/j.jenvman.2009.01.001

Satria, A., Matsida, Y. (2004). Decentralization Policy: An Opportunity for Strengthening Fisheries Management System ?._The Journal of Environment \& Development. 13(2), 179-196.https://doi. org/10.1177/1070496504264969

Thrane, M., Nielsen, E. H., Christensen, P. (2009). Cleaner production in Danish fish processing-experiences, status and possible future strategies. Journal of Cleaner Production, 17(3), 380-390. https://doi.org/10. 1016/ j.jclepro.2008. 08.006

Tomlinson, R. (1990). Review Planning local economic development: Theory and Practice, By Edward J Blakely, Sage publications. Development Southern Africa, 7(4), 743-750. https://doi.org/10. 1080/ 03768359008439548

Undang-Undang Nomor 20 tahun 2008 Tentang Usaha Mikro, Kecil, dan Menengah (UMKM).

Yang, Z., Li, S., Chen, B., Kang, H., Huang, M. (2016). China's Aquatic product Processing Industry: Policy Evolution and Economic Performance. Trends in Food Science \& Technology, 8, 149154. https://doi.org/10.1016/j.tifs.2016. 09.004

\section{BIODATA PENULIS}

Sigit Riyanto, lahir 27 September 1986 di Kabupaten Sragen. Magister Pembangunan Wilayah dan Kota Universitas Diponegoro Semarang. Bekerja di UPTD Metrologi Legal Dinas Perdagangan Kota Semarang sebagai Penera.

Fadjar Hari Mardiansyah, lahir 29 September 1969 di Jakarta. Doktor Perencanaan Wilayah dan Kota dari Université Paris Est (UPE) Perancis Bekerja. Saat ini bekerja sebagai Dosen di Program Studi Perencanaan Wilayah dan Kota Universitas Diponegoro. 